\title{
PENGGUNAAN MODEL GUIDE DISCOVERY DALAM PEMBELAJARAN BAHASA ARAB DAN PENGARUHNYA TERHADAP MAHARAH AL-KALAM
}

\author{
Neneng Gusnidar \\ Program Pascasarjana Universitas Muhammadiyah Sumatera Barat \\ Email: nenenggusnidar@gmail.com
}

\begin{abstract}
Arabic language learning until now is faced with various problems, therefore it takes an innovation from teachers such as the use of the latest capital, not even one of the teachers to test a learning model in order to get the appropriate model. This research aims to find out the influence of Guide Discovery's learning model on the maharah al-kalam class X MAN 4 Pasaman Barat. The method used in this research is quantitative research using pseudo-experiments. The study population of 125 people, from which a sample of 71 consisted of 35 classes of experiments and 36 control classes, te normality tests, homogeneity tests and hypothesis tests is a way of analyzing. The results were found to be with an average of 75.68 experiment class normality tests while the control classes with an average of 64.08 Testing normality of the L.C. expriation class were 0.5276< Ltabel0.1478 and control classes $L_{\text {count }} 0.1473<L_{\text {table }} 0.1478$ for $\alpha 0.5$, Then the data of the experiment class and the normal distributed control class. The data homogeneity test results of the two groups obtained $F_{\text {hitung }}<F_{\text {tabel, }}$, is $1.0057<1.0294$ so the homogeneous data $\alpha 0.5$. While the hypothesis test obtained $T_{\text {count }}>T_{\text {table }}$ results for $\alpha 0.5$ is $8.00>1.88014$. Then the conclusion of $\mathrm{Hl}$ was accepted and $\mathrm{HO}$ was rejected. Based on the above explanation, it can be concluded that the influence of the guide discovery learning model has an impact on the results of learning Arabic in the maharah al-kalam aspect.
\end{abstract}

Key words: Influence, Guide Discovery, Learning Arabic, Speaking Ability

\begin{abstract}
Abstrak
Pembelajaran bahasa Arab sampai saat ini dihadapkan terhadap berbagai problematika, untuk itu dibutuhkan sebuah inovasi dari guru seperti penggunaan modal terbaru, bahkan tidak salah guru melakukan uji coba terhadap sebuah model pembelajaran dalam rangka mendapatkan model yang sesuai.Penelitian ini bertujuan untuk mengetahui pengaruh model pembelajaran Guide Discovery terhadap maharah al-kalam kelas X MAN 4 Pasaman Barat. Metode yang dipakai dalam riset ini ialah penelitian kuantitatif dengan menggunakan eksperimen semu. Populasi penelitian 125 orang, dari populasi tersebut dijadikan sampel sebanyak 71 yang terdiri dari 35 kelas eksperimen dan 36 kelas kontrol, uji normalitas, uji homogenitas dan uji hipotesis ialah suatu cara yang dipakai untuk menganalisis. Hasil riset yang ditemukan adalah dengan rata-rata hasil belajar kelas eksperimen yaitu 75,68 sedangkan kelas konrol dengan rata-rata 64,08 Pengujian normalitas kelas eksprimen $L_{\text {hitung }}-0,5276<L_{\text {tabel }} 0,1478$ dan kelas kontrol $L_{\text {hitung }} 0,1473<L_{\text {tabel }} 0,1478$ untuk $\alpha 0,5$, maka data kelas eksperimen dan kelas kontrol berdistribusi normal. Hasil uji homogenitas data dari dua kelompok diperoleh $F_{\text {hitung }}<F_{\text {tabel, }}$ ialah 1,0057<1,0294 jadi data homogeny a0,5. Sedangkan
\end{abstract}


uji hipotesis didapatkan hasil $T_{\text {hitung }}>T_{\text {tabel }}$ untuk $\alpha 0,5$ adalah8,00>1,88014. Maka diperoleh kesimpulan $H_{1}$ diterima dan $H_{0}$ ditolak. Berdasarkan penjelasan di atas maka bisa disimpulkan bahwa pengaruh model pembelajaran guide discovery learning memberikan dampak terhadap hasil belajar bahasa Arab dalam aspek maharah al-kalam.

Kata Kunci: Pengaruh, Guide Discovery, Pembelajaran Bahasa Arab, Kemampuan Berbicara

\section{PENDAHULUAN}

Pembelajaran bahasa Arab sampai hari ini tidak luput dari berbagai permasalahan baik dari aspek metode, (Demchuk et al., 2015) media pembelajaran (Mohammad Nasrullah, 2017), pendekatan, strategi, (Mei et al., 2017) sumber belajar, (Wekke, 2017), (Ritonga et al., 2020b), bahkan guru itu sendiri (El-Omari \& Bataineh, 2018) dan peserta didik (Ghenghesh, 2010), (Triarisanti \& Purnawarman, 2019) serta internal bahasa Arab yang berbeda dengan bahasa lain (Effendi, 2013). Untuk itu, guru sebagai inovator dituntut untuk dapat melakukan inovasi terhadap berbagai aspek yang terdapat dalam sistem pembelajaran (Carless, 2013). Inovasi itu dituntut guna meningkatkan hasil pembelajaran (Kasem, 2016), (Susanti et al., 2020), (Tukimin et al., 2018), karena perkembangan zaman membutuhkan pembaharuan-pembaharuan yang sesuai dengan kebutuhan.

Sebagai bagian dari bentuk inovasi yang dimaksud ialah berupa pengetahuan guru terhadap berbagai model pembelajaran serta penerapannya secara baik dalam pembelajaran (Team, 2016), (Kovacs, 2017). Guru harus memiliki wawasan yang luas terkait dengan segala aspek yang terkait dengan pendidikan dan pengajaran (Wong, 2018). Sejalan dengan pandangan-pandangan di atas, model pembelajaran guide discovery pada pembelajaran bahasa Arab masih jarang digunakan oleh para pendidik, padahal penggunaan model tersebut memberikan dampak yang baik terhadap peningkatan kemampuan bahasa Arab (Apdoludin et al., 2017).

Mahyudin juga mengungkapkan bahwa model diskoveri sebagai strategi pembelajaran bahasa Arab lebih sesuai dengan teori pembelajaran karena mendukung kemandirian peserta didik (Mahyudin, 2014), Yusuf dan Wekke juga menegaskan bahwa discovery learning sebagai model pembelajaran yang didasarkan pada pembelajaran konstruksi menuntut kemandirian peserta didik untuk belajar secara aktif, guru memberikan penjelasan pada materi-materi yang kurang jelas (Yusuf \& Wekke, 2015). Kedua pendapat ini kiranya menjadi landasan bagi peneliti untuk melakukan eksperimen terhadap model pembelajaran guide discovery dalam pembelajaran bahasa Arab di MAN 4 Pasaman Barat untuk melihat pengaruhnya terhadap keterampilan berbicara bahasa Arab di kalangan peserta didik.

Penelitian ini perlu dilakukan mengingat kemampuan berbicara (maharah al-kalam) sebagai salah satu dari empat keterampilan berbahasa (Jassem, 2015) menjadi salah satu kompetensi yang paling sulit untuk dicapai peserta didik non Arab (Yaqub, 2012) termasuk siswa MAN 4 Pasaman. Pernyataan ini juga didasarkan pada analisis terhadap dokumen hasil studi peserta didik bidang studi bahasa Arab yang menunjukkan kemampuan mereka dalam menjawab pertanyaan 
setiap akhir semester, karena dalam buku rapor mereka tidak jarang yang mendapatkan nilai 90 bahkan 98. Namun ketika peneliti mengajak mereka untuk berbicara dan berkomunikasi menggunakan bahasa Arab terlihat ada kekhawatiran dan ketidakberanian mereka untuk mengucapkan apa yang mereka pikirkan dan menjawab apa yang ditanyakan.

Fenomena ini mengindikasikan adanya kesalahan model pembelajaran yang diterapkan selama ini, untuk itu pembaharuan model yang mengarahkan peserta didik untuk lebih berani dalam berbuat dan bertindak serta bertutur dibutuhkan dalam meningkatkan kemampuan berbicara peserta didik. Sejalan dengan itu, model pembelajaran guide discovery sebagaimana telah diujicobakan oleh para peneliti terdahulu memberikan dampak terhadap hasil pembelajaran (Singaravelu, 2012), (Hanafi, 2016), (Esmailzadeh et al., 2019), Wati dan Sartiman juga mengungkapkan bahwa setelah digunakannya model discovery learning terdapat pengaruhnya terhadap peningkatan hasil. Uji yang diperolehnya adalah $\mathrm{T}_{\text {hitung }}>$ $\mathrm{T}_{\text {tabel }}$ yaitu 2,593>2,000 dengan taraf signifikan $\alpha=0,05$ (Wati \& Sartiman, 2019). Dari beberapa penelitian di atas maka peneliti membuat anggapan sementara bahwa penggunaan guide discovery learning mempengaruhi keterampilan berbicara bahasa Arab peserta didik.

Berdasarkan hipotesis tersebut maka penelitian ini akan menjawab Seberapa besar pengaruh penggunaan guide discovery learning terhadap kemampuan berbicara bahasa Arab siswa kelas X MAN 4 Pasaman Barat? Sejalan dengan itu tujuan penelitian ini dimaksudkan untuk menjelaskan berapa besar pengaruh penggunaan guide discovery learning terhadap kemampuan berbicara bahasa Arab siswa kelas X MAN 4 Pasaman Barat.

\section{METODOLOGI PENELITIAN}

Penelitian ini dirancang menggunakan metode kuantitatif dengan pendekatan quasi eksperimen, yakni melakukan ujicoba terhadap penggunaan model discovery learning dalam pembelajaran bahasa Arab. Ujicoba dilakukan dengan melibatkan 2 kelas, yaitu: 1) Kelas X Jurusan IPS dijadikan sebagai kelas eksperimen dengan jumlah siswanya sebanyak 35 orang, 2) Kelas X Jurusan IPA dijadikan sebagai kelas control dengan jumlah siswanya 36 orang, oleh karena itu jumlah sampelnya sebanyak 71 yang terdiri dari kelas eksperimen dan kelas control.

Data penelitian ini ialah merupakan data primer, yakni hasil belajar bahasa Arab kelas X pada aspek keterampilan berbicara. Data penelitian ini didapatkan dari pretest dan posttest, yakni peneliti melakukan uji kemampuan berbicara bahasa Arab terhadap kedua kelas sebelum dan setelah diadakan eksperimen. Data yang didapat dari kedua cara tersebut kemudian dianalisis secara statistik,

\section{HASIL PENELITIAN DAN PEMBAHASAN}

Dengan Bukti-bukti yang dijelaskan, maka didapatkan dari hasil test bidang studi bahasa Arab, dalam aspek maharah al-kalam yang diberikan pada kelas eksperimen, dengan memakai model pembelajaran guide discovery dengan jumlah siswa 35. Berikutnya akan diungkapkan hasil belajar bahasa Arab pada aspek keterampilan berbicara peserta didik kelas X IPA MAN 4 Pasaman Barat sebagaimana pada grafik berikut: 


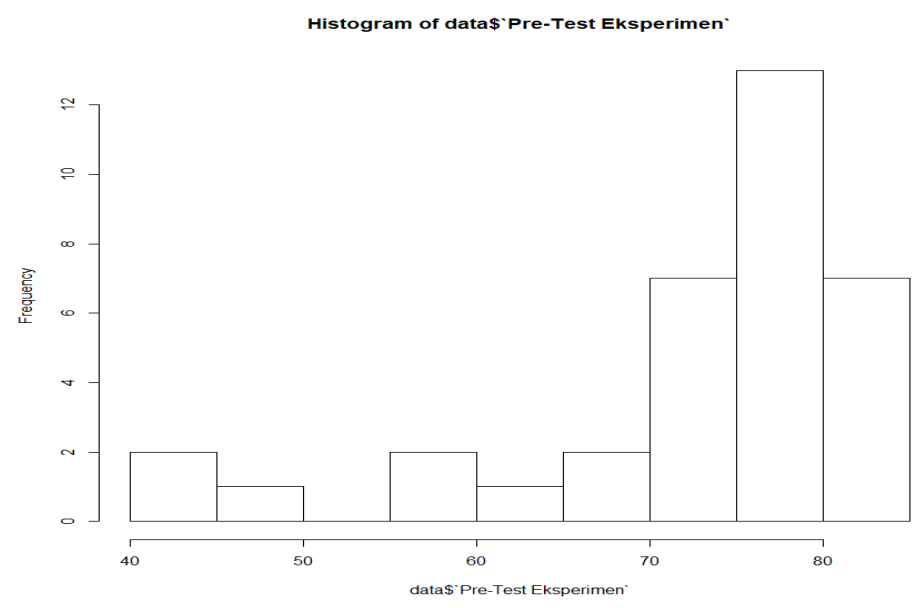

Gambar 1. Histogram data Pre Test Kelas Eksperimen Histogram of data\$'Post-Test Eksperimen'

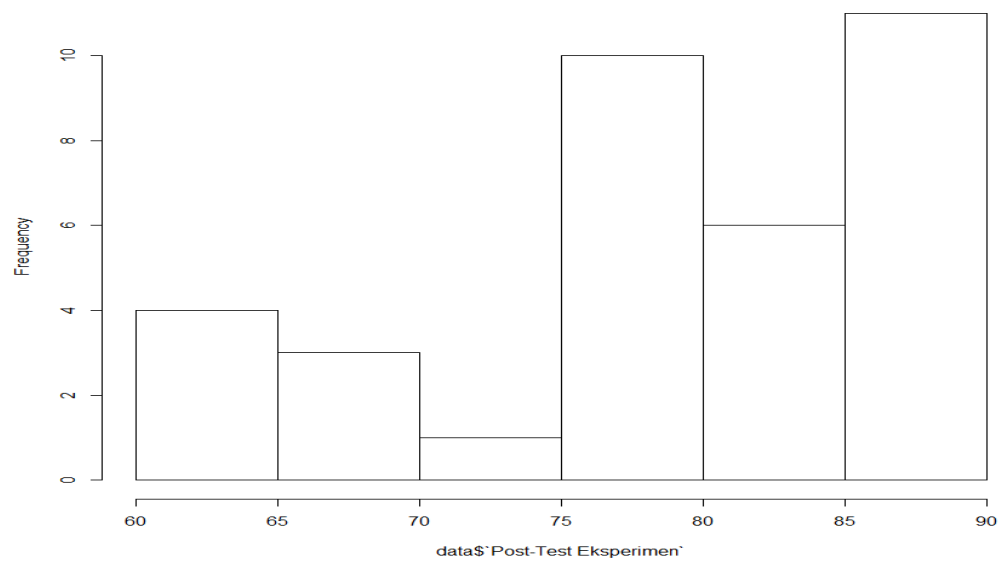

Gambar 2. Histogram data Post Tes Kelas Eksperimen

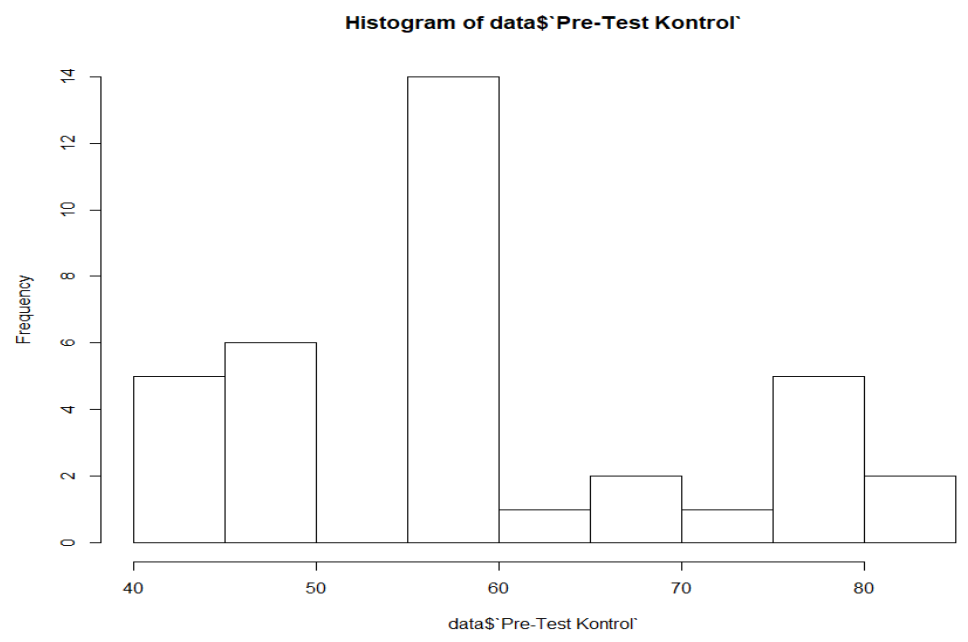

Gambar 3. Histogram data Pre Test Kelas Kontrol 


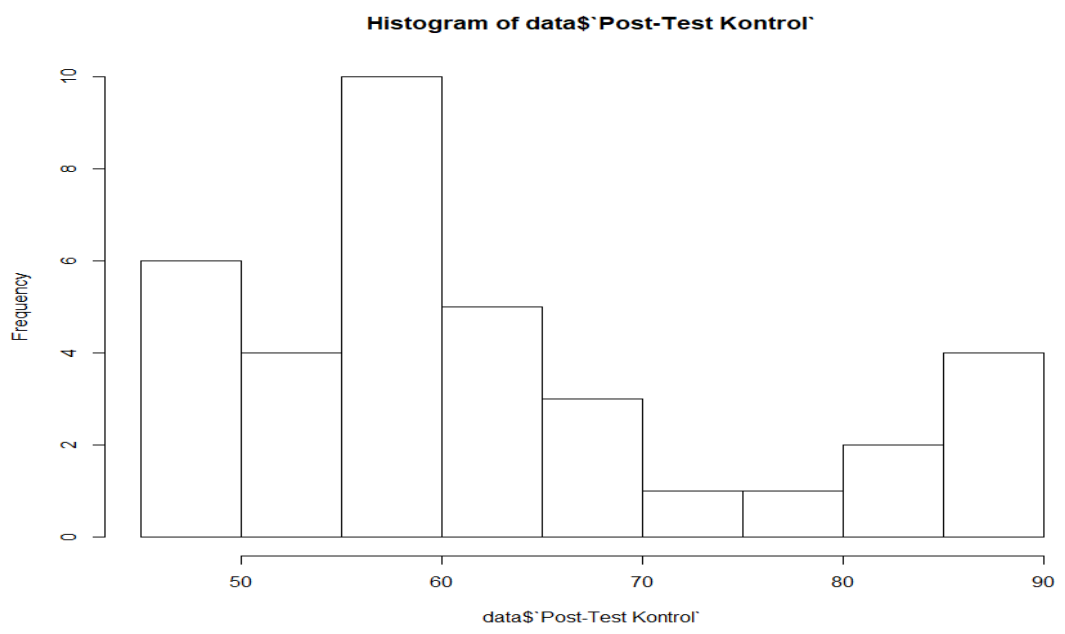

Gambar 4. Histogram data Post Test Kelas Kontrol

Data yang terdapat pada ke empat histogram di atas ketika dilakukan analisis deskriptif maka hasilnya dapat dilihat sebagaimana pada table 1 di bawah ini:

Tabel 1. Hasil Analisis Deskriptif

\section{Descriptive Statistics}

\begin{tabular}{|l|r|r|r|r|r} 
& N & \multicolumn{1}{c|}{ Minimum } & Maximum & \multicolumn{1}{c|}{ Mean } & \multicolumn{1}{c}{ Std. Deviation } \\
\hline Pre Test Eksperimen & 35 & 40 & 84 & 73.20 & 11.440 \\
\hline Post Test Eksperimen & 35 & 63 & 88 & 79.74 & 8.469 \\
\hline Pre Test Kontrol & 36 & 40 & 84 & 59.44 & 13.203 \\
\hline Post Test Kontrol & 36 & 45 & 88 & 64.08 & 12.934 \\
\hline Valid N (listwise) & 35 & & & &
\end{tabular}

Analisis deskriptif seperti yang ada pada table 1 bermanfaat untuk mendeskripsikan data penelitian sesuai dengan keperluan peneliti.

Table 2. Uji Normalitas

Tests of Normality

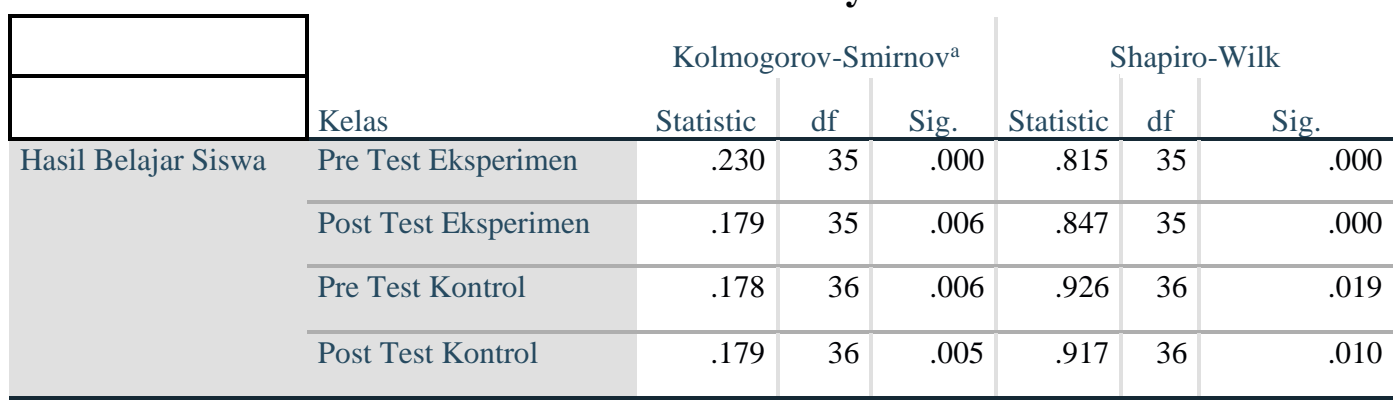

a. Lilliefors Significance Correction

Uji normalitas dilakukan untuk mengetahui apakah data berdistibusi normal atau tidak. Data yang berdistribusi normal meruakan syarat mutlak untuk melakukan uji statistik parametrik (uji paired sample t test dan uji independent sample t test. Pada penelitian ini akan digunakan dua macam uji normalitas yaitu, uji kolmogorov-smirnov dan ui shapiro-wilk.

Berdasarkan hasil uji normalitas di atas, diketahui nilai signifikansi (Sig.) didapatkan untuk semua data pada uji kolmogorov-smirnov maupun uji shapirowilk didapatkan nilai seluruhnya kurang dari 0,05. Karena syarat data dinyatakan 
berdistribusi normal pada kedua uji tersebut adalah nilai signifikansi (sig.) adalah lebih dari 0,05. Oleh karena itu, dapat dinyatakan bahwa seluruh data tidak berdistribusi normal. Karena data tidak berdistribusi normal, maka kita tidak dapat melakukan uji statistik parametrik. Sebagai gantinya kita akan melakukan uji Wilcoxon dan uji Mann Whitney.

\begin{tabular}{llr|r|r}
\multicolumn{5}{c}{ Ranks } \\
& & $\mathrm{N}$ & Mean Rank & Sum of Ranks \\
\hline Post Test - Pre Test & Negative Ranks & $0^{\mathrm{a}}$ & .00 & .00 \\
\cline { 2 - 5 } & Positive Ranks & $35^{\mathrm{b}}$ & 18.00 & 630.00 \\
\cline { 2 - 5 } & Ties & $0^{\mathrm{c}}$ & & \\
\cline { 2 - 5 } & Total & 35 & \\
\hline a. Post Test < Pre Test \\
$\begin{array}{l}\text { b. Post Test }>\text { Pre Test } \\
\text { c. Post Test }=\text { Pre Test }\end{array}$
\end{tabular}

Test Statistics ${ }^{\mathbf{a}}$

\begin{tabular}{lr}
\multicolumn{2}{c}{ Post Test - Pre Test } \\
\hline$Z$ & $-5.249^{\mathrm{b}}$ \\
\hline Asymp. Sig. (2-tailed) & .000 \\
\hline $\begin{array}{l}\text { a. Wilcoxon Signed Ranks Test } \\
\text { b. Based on negative ranks. }\end{array}$ &
\end{tabular}

\section{Hasil uji Wilcoxon}

Uji Wilcoxon bertujuan untuk mengetahui ada tidaknya perbedaan ratarata data sampel yang saling berpasangan. Uji ini merupakan bagian dari statistik non-parametrik, sehingga tidak diperlukan data yang berdistribusi normal. Uji Wilcoxon biasanya digunakan sebagai alternatif dari uji paired sample $t$ test apabila data tidak berdistribusi normal. Data yang digunakan adalah data kelas eksperimen saja.

Berdasarkan output uji Wilcoxon di atas, diketahui terdapat dua tabel yaiu Ranks serta Test Statistics. Pada tabel Ranks terdapat tiga baris yaitu negative rank, posiive rank, dan ties. Negarive rank menggambarkan apakah ada data yang berselisih negatif dari Pre Test ke Post Test, sementara sebaliknya untuk Positive rank, sedangkan ties adalah data tetap. Dari hasil tersebut didapatkan bahwa seluruh data tidak ada yang mengalami penurunan dari Pre Test ke Post Test.

Berdasarkan hasil output Test Statistics, hipotesis akan diterima apabila nilai Asymp.Sig. kurang dari 0,05. Hasil output uji Wilcoxon di atas, didapatkan nilai Asymp.Sig. bernilai 0,000 yang berarti kurang dari 0,05. Akibatnya, hipotesis dapat diterima. Artinya ada perbedaan antara hasil belajar saat Pre Test dan Post Test. Kesimpulannya, ada pengaruh penggunaan model Guide Discovery terhadap pembelajaran.

Test of Homogeneity of Variances

\begin{tabular}{llr|r|r|r} 
& & Levene Statistic & df1 & df2 & Sig. \\
\hline Hasil Belajar & Based on Mean & 4.918 & 1 & 69 & .030 \\
\cline { 2 - 6 } Siswa & Based on Median & 2.897 & 1 & 69 & .093 \\
\cline { 2 - 6 } & $\begin{array}{l}\text { Based on Median and } \\
\text { with adjusted df }\end{array}$ & 2.897 & 1 & 53.31 & .095 \\
\cline { 2 - 6 } & $\begin{array}{l}\text { Based on trimmed } \\
\text { mean }\end{array}$ & 4.873 & 1 & 69 & .031 \\
\hline
\end{tabular}

Hasil Uji Homogenitas 
Berdasarkan hasil Uji homogenitas, didapatkan nilai Signifikansi (Sig.) Random on Mean adalah 0,030 kurang dari 0,05. Akibatnya dapat disimpulkan bawa varians data tidak homogen.

\begin{tabular}{lrr} 
& $\begin{array}{c}\text { Test Statistics } \\
\text { Hasil Belajar Siswa }\end{array}$ \\
\hline Mann-Whitney U & & 214.500 \\
\hline Wilcoxon W & & 880.500 \\
\hline$Z$ & & -4.808 \\
\hline Asymp. Sig. (2-tailed) & & .000 \\
\hline a. Grouping Variable: Kelas & Hasil Uji Mann-Whitney &
\end{tabular}

Uji Mann-Whitney digunakan untuk mengetahui ada tidaknya perbedaan rata-rata sampel yang tidak berpasangan. Uji ini merupakan bagaina dari uji statistik non-parametrik, sehingga data yang digunakan tidak perlu berdistribusi normal dan homogen. Uji ini digunakan sebagai alternatif dari uji independent sample t test apabila data penelitian tidak berdistribusi normal dan tidak homogen.

Hipotesis uji Mann-Whitney akan diterima apabila nilai Asymp.Sig. kurang dari 0,05 dan berlaku sebaliknya. Berdasarkan output uji Mann-Whitney diketahui bahwa nilai Asymp.Sig. sebesar 0,000 kurang dari 0,05. Akibatnya dapat dinyatakan hipotesis dapat diterima, yaitu adanya perbedaan hasil belajar antara kelas Kontrol dengan kelas Eksperimen. Dengan demikian dapat disimpulkan bahwa ada pengaruh penggunaan ada pengaruh penggunaan model Guide Discovery terhadap pembelajaran.

Pengaruh model guide discovery lebih berhasil jika dibandingkan dengan hasil belajar peserta didik yang menggunakan cara belajar yang bersifat tradisional yang digunakan salah seorang guru khususnya pada mata pelajaran bahasa Arab aspek maharah al-kalam di kelas X Madrasah Aliyah Negeri Kajai 4 Pasaman Barat semester satu tahun ajaran 2019/2020. Keberhasilan yang sama dengan persentase yang berbeda juga didapatkan oleh Wati dan Sartiman pada tahun 2019 (Wati \& Sartiman, 2019). Pengaruh ini tidak terlepas dari meningkatnya motivasi siswa dengan cara belajar yang baru yang dipakai oleh guru, sehingga peserta didik dalam mengungkapkan sesuatu yang ada dipikiran mereka dengan menggunakan bahasa Arab lebih memberanikan diri dan ada rasa percaya diri.

Kemampuan berbahasa Arab seperti maharah al-kalam membutuhkan kepercayaan diri dari peserta untuk menunjukkan kemampuannya (Sartika \& Ritonga, 2020), seperti yang diungkapkan oleh Aprianto dan kawan-kawan bahwa untuk mewujudkan kemampuan berbahasa yang baik peserta didik harus senantiasa mengadakan latihan (Aprianto et al., 2020), selain itu pemilihan metode yang tepat seperti yang diungkapkan oleh Hakim dan Ritonga menjadi salah satu indicator ketercapaian tujuan pembelajaran (Hakim \& Ritonga, 2018), sementara Ritonga mengungkapkan sumber pembelajaran yang tepat akan merealisasikan tujuan pembelajaran yang diharapkan (Ritonga, 2017), (Ritonga et al., 2020a). 
Pengaruh model guide discovery lebih tinggi dibandingkan hasil belajar siswa yang menggunakan model pembelajaran yang selama ini digunkana oleh guru khususnya pada mata pelajaran bahasa Arab aspek maharah al-kalam di kelas X Madrasah Aliyah Negeri 4 Pasaman Barat semester ganjil tahun pelajaran 2019/2020. Hasil yang sama dengan persentase yang berbeda juga didapatkan oleh Wati dan Sartiman pada tahun 2019 ketika melakukan penelitian di MAN 1 Krui Pesisir Barat (Wati \& Sartiman, 2019). Pengaruh itu tidak terlepas dari meningkatnya motivasi peserta didik dengan model pembelajaran baru yang digunakan oleh guru, sehingga mereka lebih berani untuk mengungkapkan apa yang mereka pikirkan dengan menggunakan bahasa Arab.

Pembelajaran dengan menggunakan model discovery sebagaimana yang diungkapkan oleh Juni dkk mempengaruhi kualitas dan kemampuan kognitif peserta didik serta hasil pembelajaran (Junina et al., 2020), sementara Irawan dkk juga mengungkapkan bahwa metode diskoveri lebih berpengaruh dibanding metode konvensional dalam meningkatkan hasil pembelajaran (Irawan et al., 2019). Dari beberapa hasil penelitian yang disebutkan di atas kebaruan penelitian ini ialah berada pada pembelajaran bahasa Arab dengan metode discoveri dapat meningkatkan keterampilan berbahasa Arab siswa.

\section{KESIMPULAN}

Terdapat pengaruh model Guide Discovery terhadap kelas hasil belajar bahasa Arab aspek maharah al-kalam di Kelas X MAN 4 Pasaman Barat, dengan rata-rata kelompok eksperimenmemperoleh nilai rata-rata 75,68, sedangkan pada kelompok kontrol ialah nilai rata-rata 64,08. Pada pengujian normalitas kelas eksperimen $\mathrm{L}_{\text {hitung }}<$ dari $\mathrm{L}_{\text {tabel}}$, dimana $\mathrm{L}_{\text {hitung }}=-0,5276<$ dari $\mathrm{L}_{\text {tabel }}=0,1478$ dan kelompok kontrol $\mathrm{L}_{\text {hitung }}=0,1473<$ dari $\mathrm{L}_{\text {tabel }}=0,1478$ untuk $\boldsymbol{\alpha} 0,5$, maka data kelompok kontrol dan kelompok eksperimen berpeluang normal. Dan pada pengujian Homogenitas data dari dua kelas tersebut diperoleh $F_{\text {hitung }}<F_{\text {tabel, }}$ yaitu $1,0057<1,0294$ maka kedua kelompok tersebut mempunyai varians yang sama untuk $\boldsymbol{\alpha}$ 0,5. Jika dibandingkan dengan pengujian Hipotesis yang memakai test didapatkan hasil $t_{\text {hitung }}>\mathrm{t}_{\text {tabel }}$ untuk $\boldsymbol{\alpha} 0,5$ yaitu 8,00>-1,88014. Maka dapat disimpulkan $\mathrm{H}_{1}$ diterima dan $\mathrm{H}_{0}$ ditolak. Data ini menunjukkan hipotesis penelitian diterima, yakni adanya pengaruh dalam pemakaian model pemebelajaran guide discovery terhadap hasil belajar bahasa Arab dengan aspek maharah al-kalam.

\section{DAFTAR PUSTAKA}

Apdoludin, Wiryotinoyo, M., \& Hadiyanto. (2017). Analysis and Discovery Model for Learning Yellow Book in Pesantren. The Online Journal of New Horizons Inn Education, 7(4), 1-11.

Aprianto, Ritonga, M., Marlius, Y., \& Nusyur, R. (2020). The Influence of Using Audio- lingual Method on Students' Speaking Skill in Madrasah Diniyah Takmiliyah Awwaliyyah. Izdihar: Journal of Arabic Language Teaching, Linguistics, and $\quad$ Literature, 3(2), 149-162. https://doi.org/https://doi.org/10.22219/jiz.v3i2.12514

Carless, D. (2013). Innovation in Language Teaching and Learning. The Encyclopedia of Applied Linguistics, January, 1-5. 
https://doi.org/10.1002/9781405198431.wbeal0540

Demchuk, A., Karavaeva, Y., Kovtun, Y., \& Rodionova, S. (2015). Competencies, Learning Outcomes and Forms of Assessment: the Use of Tuning Methodology in Russia. Tuning Journal for Higher Education, 3(1), 149-185. https://doi.org/10.18543/tjhe-3(1)-2015pp149-185

Effendi, A. (2013). Zhawahir al-Lughah al-'Arabiyyah wa Musykilat 'Amaliyyah Ta'limiha Linnathiqina bi Ghairiha. Journal of English and Arabic Language Teaching (JEALT), 2(2), 1-27.

El-Omari, A. H., \& Bataineh, H. M. (2018). Problems of Learning Arabic by Non-Arabic Speaking Children: Diagnosis and Treatment. Journal of Language Teaching and Research, 9(5), 1095-1101. https://doi.org/10.17507/jltr.0905.14

Esmailzadeh, F., Lotfi, S. A. T., \& Tabar, N. A. (2019). The Effects of Guideddiscovery, Self-discovery, and Situational-presentation Techniques on Learning Conditional Sentences in English. Applied Linguistics Research Journal, 3(3), 51-63. https://doi.org/10.14744/alrj.2019.27247

Ghenghesh, P. (2010). The Motivation of Learners of Arabic: Does it Decrease with Age? Journal of Language Teaching and Research, 1(3), 235-249. https://doi.org/10.4304/jltr.1.3.235-249

Hakim, R., \& Ritonga, M. (2018). A Study of Religion Education Method With Multicultural Insight. International Seminar on Islamic Education (ISIE 2018) Faculty of Islamic Religion, Universitas Muhammadiyah Ponorogo, July 07th, 2018, Isie 2018, 81-97.

Hanafi, H. (2016). The Effect of Discovery Learning Method Application on Increasing Students' Listening Outcome and Social Attitude. Dinamika Ilmu, 16(2), 291. https://doi.org/10.21093/di.v16i2.552

Irawan, A., Ruslan, D., \& Mare, A. S. (2019). The Effects of Learning Models of Discovery Learning and Learning Interest on Social Science Learning Outcomes in Grade VII of Junior High School of Al-Azhar Medan. BirLEJournal Budapest International Research and Critics Linguistics and Education, 2(3), 94-105.

Jassem, J. 'Ali. (2015). al-Maharat al-Lughawiyyah wa Ma'ayir Judatuha (Issue 1). Markaz Ishar Linnasyr wa al-Tawziy'.

Junina, I., Halim, A., \& Mahidin. (2020). The Effect of Discovery LearningBased Worksheet on Students' Metacognition Skill and Learning Outcomes. AICMSTE, 1-6. https://doi.org/10.1088/17426596/1460/1/012100

Kasem, A.-H. (2016). Innovation in Language Education: Enriching Arabic Language Learner Experiences and Proficiency in2D and 3D Environments. IOSR Journal of Humanities and Social Science (IOSRJHSS), 21(09), 40-46. https://doi.org/10.9790/0837-2109064046

Kovacs, H. (2017). Learning and Teaching in Innovation: Why it is Important for Education in 21st Century. Neveléstudomány, 5(2), 45-60. https://doi.org/10.21549/ntny.18.2017.2.4

Mahyudin, E. (2014). Model Pembelajaran Diskoveri Sebagai Strategi Pembelajaran Bahasa Arab. ARABIYAT: Jurnal Pendidikan Bahasa Arab Dan Kebahasaaraban, 1(2), 195-208. https://doi.org/10.15408/a.v1i2.1139 
Mei, S. Y., Ju, S. Y., \& Mohd, A. B. (2017). Cooperative Learning Strategy in Teaching Arabic for Non Native Speakers. European Journal of Social Sciences Education and Research, 11(2), 262-267. https://doi.org/10.26417/ejser.v11i2.p261-266

Mohammad Nasrullah, Y. (2017). Atsar Istikhdam al-Wasa'il al-Ta'limiyyah fi Ta'lim al-Lughah al-'Arabiyyah fi Jami'ah Indunisiya al-Tarbawiyyah bi Jazirah Jawa al-Ghorbiyyah. Jurnal Al-Bayan, 9(1), 17-30.

Ritonga, M. (2017). Desain Bahan Ajar Bahasa Arab Sains dengan Pendekatan Whole Language. EDUKASI: Jurnal Pendidikan Islam, 5(2), 001-024. https://doi.org/https://doi.org/10.5281/edukasi.v5i2.287

Ritonga, M., Bustami, H., Saputra, R., Hakim, R., Mursal, Elhusen, S. K., \& Marlius, Y. (2020a). Reformulating the arabic language teaching materials within the framework of generating new cadres of Tarjih and Tajdid Ulama. International Journal of Advanced Science and Technology, 29(7), 185-190.

Ritonga, M., Bustami, H., Saputra, R., Hakim, R., Mursal, Elhusen, S. K., \& Marlius, Y. (2020b). Reformulating the Arabic Language Teaching Materials Within the Framework of Generating New Cadres of Tarjih and Tajdid Ulama Islamic Law Study Program Faculty of Islamic Religion , Muhammadiyah University of. International Journal of Advanced Science and Technology, 29(7), 185-190.

Sartika, F., \& Ritonga, M. (2020). Ta'tsir Isti'mal al-Wasa'il al-Sam'iyyah alBashariyyah "Ala Nataij Ta'lim Mufradat al-Lughah al-'Arabiyyah Lilfashl al-Rabi" fi al-Madrasah al-Ibtida'iyah al-Islamiyyah alHukumiyyah Parambahan Lambasi Payakumbuh. Alfazuna, 4(2), 144-154. http://jurnalftk.uinsby.ac.id/index.php/alfazuna/article/view/592/261

Singaravelu, G. (2012). Discovery Learning Strategies In English. I-Manager's Journal on English Language Teaching, 2(1), 57-62. https://doi.org/10.26634/jelt.2.1.1620

Susanti, E., Ritonga, M., \& Bambang, B. (2020). Pengaruh Penggunaan Media Powerpoint Terhadap Minat Belajar Bahasa Arab Siswa. Arabiyatuna: Jurnal Bahasa Arab, 4(1), 179-191. https://doi.org/10.29240/jba.v4i1.1406

Team, O. (2016). Innovating Education and Educating for Innovation: The Power of Digital Technologies and Skills (Issue 1). OECD Publishing. https://doi.org/10.1787/9789264265097-en

Triarisanti, R., \& Purnawarman, P. (2019). The Influence of Interest and Motivation on College Students' Language and Art Appreciation Learning Outcomes. International Journal of Education, 11(2), 130-135. https://doi.org/10.17509/ije.v11i2.14745

Tukimin, R., Mohd Rahimi Nik Yusoff, N., Baharudin, H., \& Hussain, F. (2018). Innovative Arabic Language Teacher: A Dream or A Hope. International Journal of Academic Research in Progressive Education and Development, 7(4), 158-165. https://doi.org/10.6007/IJARPED/v7-i4/4844

Wati, Y., \& Sartiman, S. (2019). Discovery Learning: Pengaruhnya Terhadap Hasil Belajar. Indonesian Journal of Science and Mathematics Education, 2(1), 123-129. https://doi.org/10.24042/ijsme.v2i1.3981

Wekke, I. S. (2017). Arabic Learning Material of Higher Education Muslim 
Community North Sulawesi. Dinamika Ilmu, 17(2), 175-189. https://doi.org/10.21093/di.v17i2.863

Wong, T. M. (2018). Teaching Innovations in Asian Higher Education: Perspectives of educators. Asian Association of Open Universities Journal, 13(2), 179-190. https://doi.org/10.1108/aaouj-12-2018-0032

Yaqub, M. T. (2012). Developing Speaking Skill in Arabic Learners: A Proposal for Integration of Product and Process Approaches. European Scientific Jounal, 8(29), 140-149.

Yusuf, M., \& Wekke, I. S. (2015). Active Learning on Teaching Arabic for Special Purpose in Indonesian Pesantren. Procedia - Social and Behavioral Sciences, 191, 137-141. https://doi.org/10.1016/j.sbspro.2015.04.245 